\title{
Same Buildings Different Models: Further Studies in ljo Vernacular Base Camp Architecture
}

\author{
Warebi Gabriel Brisibe, Owajionyi Lysias Frank \\ Department of Architecture, Rivers State University, Nkpolu-Oroworukwo, Port-Harcourt
}

Email address:

briswares@yahoo.com (W. G. Brisibe), owajifrank@yahoo.com (O. L. Frank)

To cite this article:

Warebi Gabriel Brisibe, Owajionyi Lysias Frank. Same Buildings Different Models: Further Studies in Ijo Vernacular Base Camp Architecture. International Journal of Architecture, Arts and Applications. Vol. 5, No. 2, 2019, pp. 50-63. doi: 10.11648/j.ijaaa.20190502.13

Received: July 9, 2019; Accepted: August 7, 2019; Published: September 3, 2019

\begin{abstract}
This study examines architectural change of cultures stemming from the same ethnic source split between their homeland and other Diasporas. This change may range from minor deviations to drastic shifts away from an architectural norm and the accumulation of these shifts within a time frame constitutes variations. Based on fieldwork data obtained from an earlier study of 33 migrant fishing base camps in Bayelsa and Bakassi, this paper focuses on identifying variations between base camp dwellings of Ijo migrant fishermen, in the Bakassi Peninsula in Cameroon and Bayelsa State in Nigeria. The research uses a socio-cultural, comparative case study approach to investigate the specifics of base camp dwelling designs. This approach gives opportunities to explore the extent of the variations between the built forms, in response to internal and external forces of cultural dynamism. The qualitative methodology adopted focused on ascertaining variations through exterior evaluation of the design features, materials and construction process of the base camp dwellings. The study draws on the idea of the inevitability of cultural and social change over time to test for possibilities of variations as proposed in the theories of cultural dynamism and evolution. The findings suggest that some levels of variations between base camps models have occurred over time thus supporting the aforementioned theory and this change is attributable to an agglomeration of factors, rather than a single factor.
\end{abstract}

Keywords: Vernacular, Architecture, Base Camps, Migrant Fishermen, Building Models, Ijo

\section{Introduction}

Migration is a common socio-economic activity in the lifestyle of artisanal fishermen of Ijo ethnic origin. The Ijos are one of 10 prominent migrant fishing tribes in the West African sub-region and the fourth largest ethnic group in Nigeria. They migrate to different locations along the inshore rivers and coastline of Nigeria and beyond following the movement of certain species of fish. This has contributed in spreading their population among other regions in Nigeria and Africa. However, their ancestral homeland has been traced to a large community in the central Niger Delta area of Nigeria currently in Bayelsa State, considered to be the ancestral home of the Ijos. These fishermen embark on two forms of migration; the first is an inter-regional and sometimes transnational form of migration, where the fishermen relocate and become settlers in other geographic regions or countries; and secondly, an inter-site or intraregional form of migration, where the fishermen carry out various short migratory or commuting trips within the region they choose to settle during different fishing seasons in the year. Other scholars refer to these two forms of migration as 'international' and 'internal' migrations [1]. Openness of the borders of the territorial waters between coastal countries in West and Central Africa were identified as the key factor that makes such international migration possible [2]. In both forms of migration, one main dwelling and a number of satellite dwellings are established. The main dwelling is known as the base camp from which they travel and establish the other satellite camps following the movement of the fish shoals.

Based on their tendency to migrate, Ijo migrant fishermen have settled in the coastal boundaries of Nigeria and Benin republic [3]; the Bakassi Peninsula and Littoral regions of Cameroon $[4,5]$; towards the North in the Lake Chad regions 
which border Nigeria, Cameroon and the Republic of Chad ${ }^{1}$; and the coastal regions of Equatorial Guinea; Gabon and the Republic of Congo [5]. So, although Ijo migrant fishermen live in five other African countries, this study is narrowed down to the comparative analysis of the dwelling models in Bayelsa (Nigeria) and Bakassi (Cameroon) only. This is in a bid to make the research scope more manageable.

The newer generations of migrant fishermen born in Diaspora, learn the techniques of the fishing trade as well as the skills required for building their vernacular dwellings by cultural transmission methods. This includes obtaining instructions by oral tradition and hands-on practice while they serve as apprentices under parents, master fishermen or elders. The designs of the dwellings were patterned after the mental blue-prints obtained from similar dwellings in their ethnic homeland in the current Bayelsa State. Previous studies have shown that as a result of cultural dynamism and ethnogenesis, changes have occurred in the vernacular dwellings of Ijo migrant fishers in these locations over time [6]. Besides internal changes, some of the external factors that caused change include; influences from other ethnic groups as a result of migration, the impact of modernisation, and intentional or non-intentional modifications [7]. But focusing mainly on external features and spatial arrangements, this paper examines two different models of the base camp dwellings to identify the traditional elements in the dwelling that have remained consistent, modified, removed or introduced in one location or the other.

The need for investigating such change in society through material culture such as vernacular architecture was emphasized by Turan. He then posits that changing conditions and variability remain one of the major characteristics of vernacular architecture. Based on this, he raises important questions concerning vernacular architecture one of which is;

How does one account for similarities and differences in examples of vernacular architecture in similar and different cultural contexts? Or, how does one explain the qualitative and quantitative differences in vernacular architecture within one society? [8].

Since then there have been other studies on understanding change in vernacular house forms over time [9, 10]. The results of this research may not necessarily address the issue of cultural change in a way that is applicable to all vernacular environments but it can contribute to the overall knowledge by examining it from the culture-specific viewpoint of Ijo migrant fishermen.

However, this paper argues that even though this is a case of the same ethnic group living in two different countries, change over time would have resulted in significant variations in the social and material culture of the group in both locations. This is based on the concept of cultural change, which emphasizes the dynamism of culture in every given society with time. Wimsatt proposes that a change in a

\footnotetext{
${ }^{1}$ Personal communication with the Assistant chief planning officer of the Nigerian Boundary Commission
}

cultural system is autonomous in five areas and as such, change amongst other aspects of the system is determined not only by external circumstances but by the nature of the system itself [11]. In essence, the tendency to change does not depend on external forces acting on it, but is inherent in any cultural system and affects all its forms of material culture. The material culture being investigated here is vernacular architecture [12]. Rapoport and Hardie argue that for vernacular architecture, "The process of culture change and associated changes to the built environment is dynamic, so that the problem is to identify persisting traditional elements, as well as disappearing, changing, or new elements in the built environment" [13]. Other scholars have since then examined the issue of continuities, discontinuities, changes and transformations in vernacular architecture over time [14, 15]. Based on this concept architecture is subject to change not only by external influences but also by its inherent tendency to do so.

In this study, the changes between the architectural built forms in both locations will be examined on three distinct grounds or categories:

Exterior Architectural Features; Variations based on external architectural features, examine issues related to all aspects of the dwelling exterior, such as the building components, materials, features, finishes, layout of the building units within the homestead, and the building form or shape.

Building Construction; Variations in internal spatial configurations are assessed differently and the focus here is on the arrangement of spaces within a building, as well as the arrangement of the different building units within the homestead.

Spatial configuration; Significant variations in the building construction process are also examined. Included in this aspect are issues related to the sub-structure, such as the differences in foundations, in addition to various aspects of the building's superstructure, such as basic building principles and the tasking sequence in the building process.

\section{Methodology}

The methodology adopted for this study was the case study approach. "Exemplary" case designs where all cases selected "reflect strong, positive examples of the phenomenon of interest" was used [16]. Following Yin's study, selecting case studies was not simply a matter of finding the most convenient or accessible site from which to collect data but to incorporate the specific reasons why the particular group of cases was required. The purpose was to ascertain the different material types, architectural features, construction processes and spatial configurations of the different case buildings in question. This was to obtain simple comparative analysis of the two base camp models and present them in tabular form.

In the Bakassi Peninsula, household heads were required to have spent a minimum of 25 years in the region before their camps were selected as case studies. This time span 
would allow for the minimum tenure of a generation to elapse. A generation may be considered as the average period that elapses before children are in position to replace their parents; it is estimated chronologically to be about 25 30years ${ }^{2}$.

The extent of the architectural variations identified between both migrant fishing societies, have been categorized in three levels and these are; major change, minor change and no change. Under each level are a given set of parameters that serve as a guide to elucidate the differences. The various attributes within each category stated will serve as substantive indicators of change. Each aspect that serves as an indicator will be examined for levels of variation separately

The above table is a summary of the level of variation of all major architectural attributes, based on a case study of 33 base camp dwellings in Bayelsa State and the Bakassi Peninsula.

Exterior Architectural and Surface Features

This analysis covers exterior architectural attributes such as the type of building materials used in migrant fishing camps in both societies. This includes materials and techniques used for roofing, fenestrations, exterior wall cladding and embankments for reclaimed landed areas. It excludes observations on types of foundations which are discussed when examining variations in construction methods.

\subsection{Exterior Wall Cladding: Materials and Techniques}

The main variation in the use of building materials are in the wall cladding components. In regions around Bayelsa, alternative materials such as cane, raffia palm fronds stripped of their leaves, and timber boards have been used, in addition to the more popular braided or woven raffia leaves for cladding external walls in base camp dwellings. In the Bakassi Peninsula, Ijo migrant fishermen appear to have remained true to one material even though the other three materials used in Bayelsa are equally found in abundance in the peninsula. Hence, only braided or woven raffia palm are found as cladding materials for dwellings occupied by Ijos in the base-camps in Bakassi.

Different techniques are employed in weaving raffia palm leaves. The leaves can be bent over a stem and attached together in vertical striations or in diagonal cross-striations. Also the palm fronds can be used whole and laid horizontally alternating the direction of flow of the leaves to create a reverse order, which gives the impression of a cross-striation technique (figure 6). All three woven forms of wall cladding are used by Ijo migrant fishermen in both Bayelsa state and Bakassi peninsula. The three other wall cladding techniques shown in table 2 are used mainly among migrant fishermen in the brackish water zones of Bayelsa state.

The $0.3 \times 3.6 \mathrm{~m}$ wooden planks utilized as a form of wall cladding are the same types used as floor boards in the stilt buildings of the base camps, which is common to both the Bayelsa and Bakassi regions. These are laid horizontally with a slight overlap or laid close together and nailed unto the structural frames (figure 8). This material is the least used by the migrant fisherman, as it requires the most financial investment among the three methods. The timber planks have to be cut using a chainsaw and transported from the forest to the camp, which adds to the increase in costs. Furthermore, it is the only material that requires the use of nails for fastening them to the joists which adds to the cost of production.

The third option also used, is the stem of the raffia palm fronds known as akporo or agbein. Whole branches of the raffia palm are cut or collected when they fall and stripped of all the leaves. After which they are arranged side by side in vertical order and tied together (figure 9). This method requires only human capital and is fixed using traditional ropes. Its cost effectiveness makes it another widely used cladding method for migrant fisher dwellings in inshore base camps, as well as offshore season camps. In table 2 a summary of the different wall cladding techniques are listed.

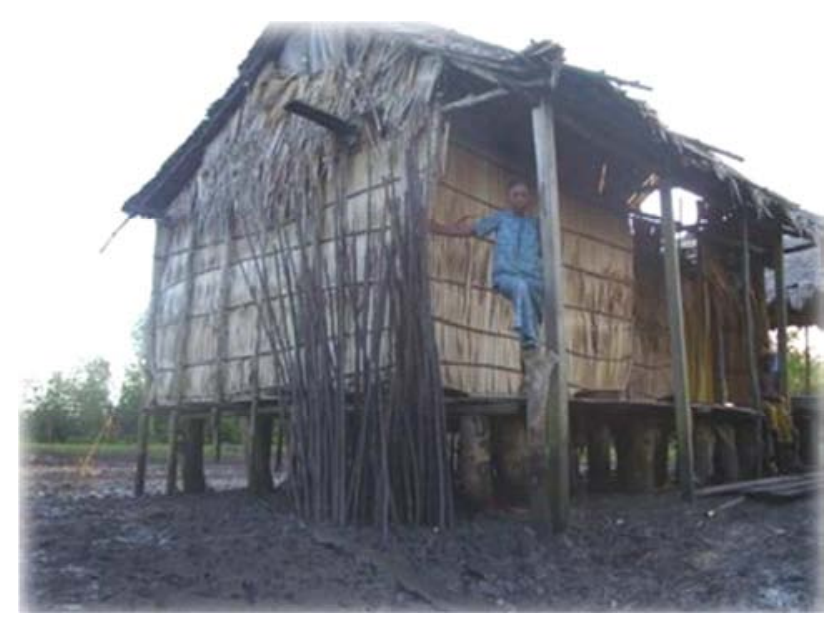

Figure 1. Vertical matting (Egbelegbene base Camp, Bakassi).

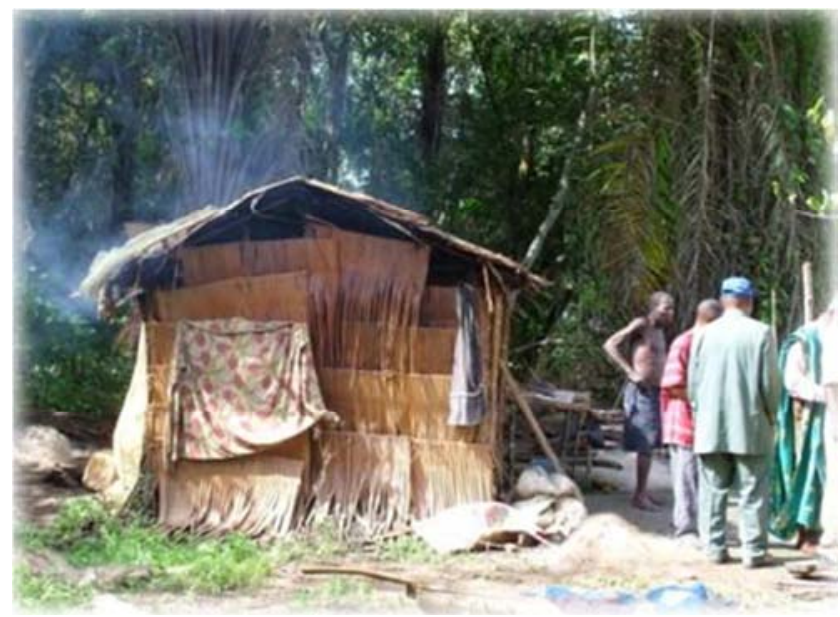

Figure 2. Vertical matting (Noelkiri base camp, Bayelsa). 


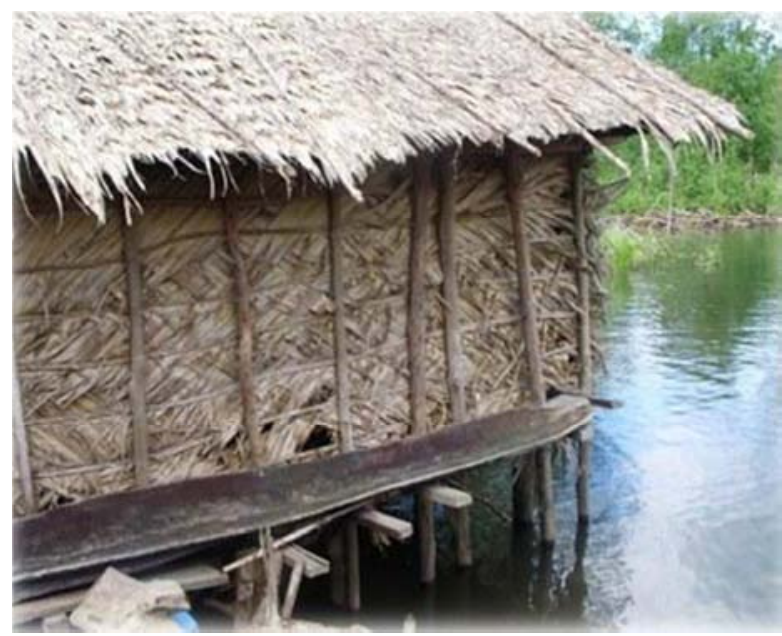

Figure 3. Diagonal wall matting (Boro base camp, Bakassi).

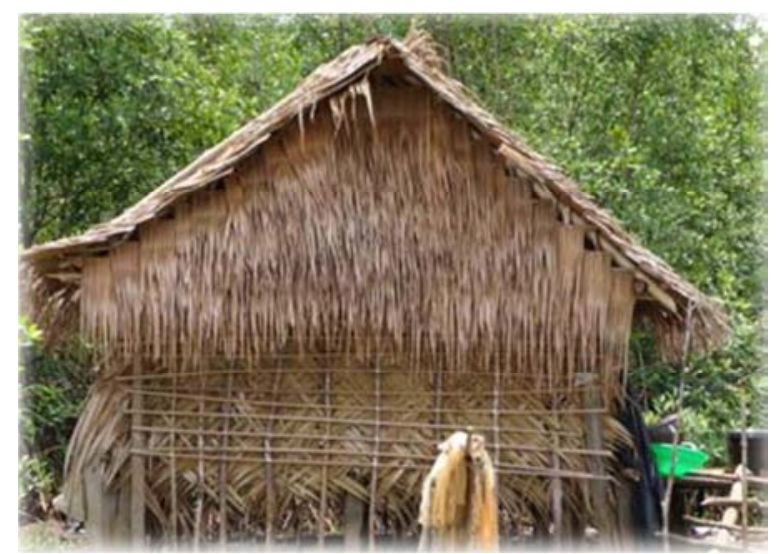

Figure 4. Diagonal wall matting (New Year base camp, Bayelsa).

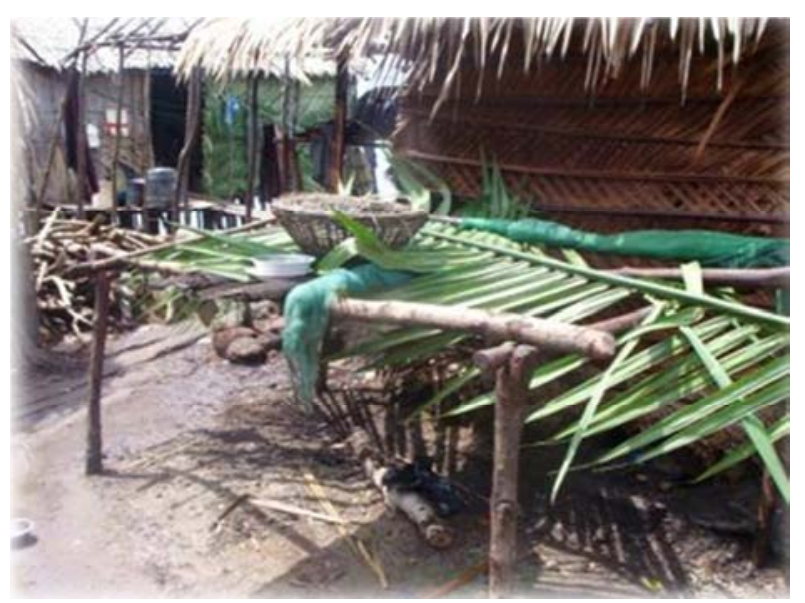

Figure 5. Whole fronds laid horizontally (Tubogbene base camp, Bakassi).

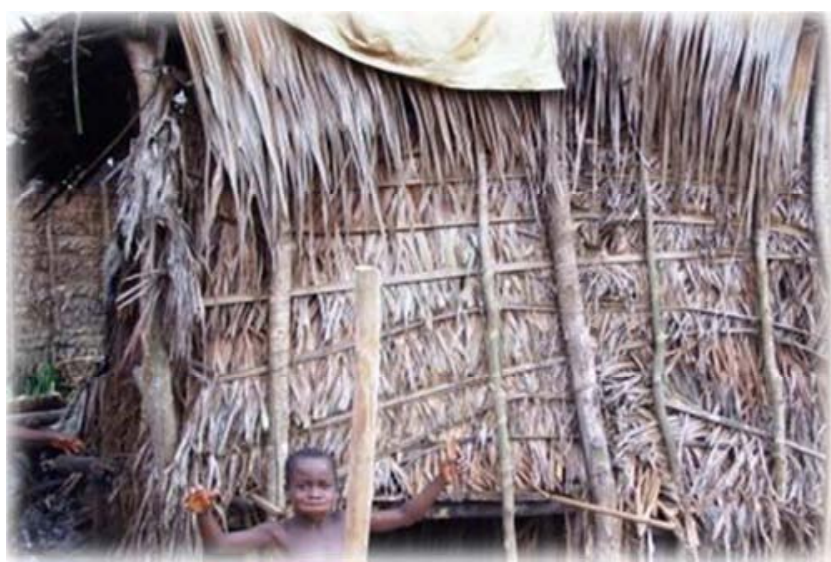

Figure 6. Whole Palm fronds laid horizontally (Aladdinkiri base camp, Bayelsa).

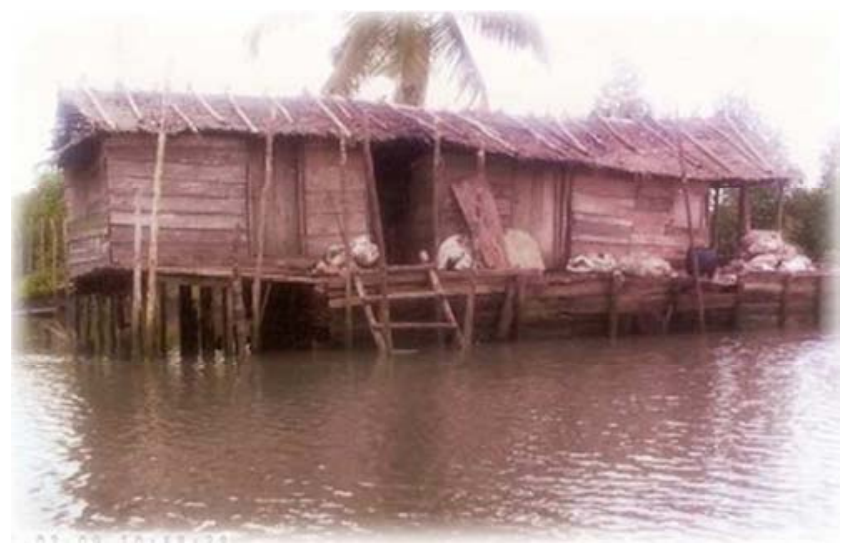

Figure 7. Wooden planks, laid horizontally (Base Camp in Brass, Bayelsa).

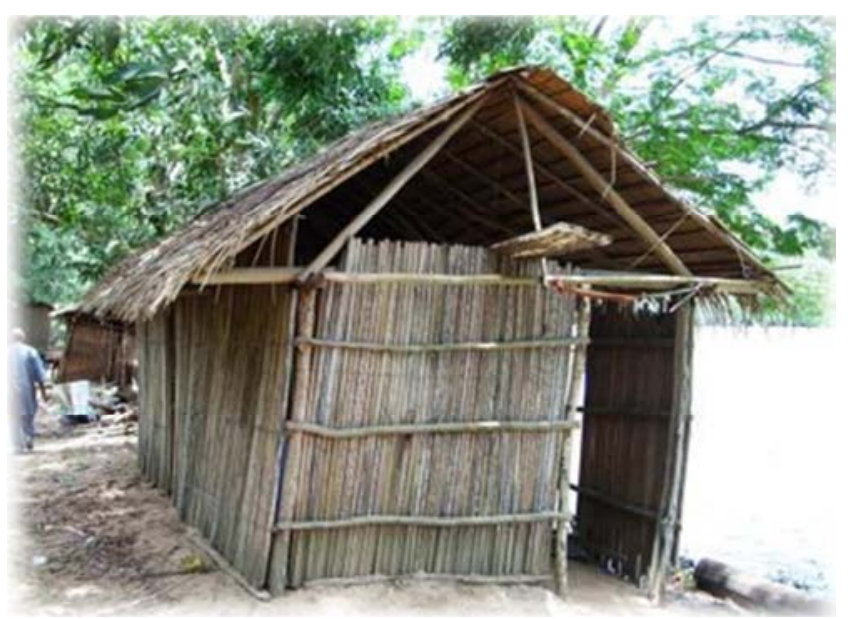

Figure 8. Palm frond stems stripped of leaves (Ekperiyai-gbene camp, Bayelsa).

Table 1. Showing levels of variation of each indicator.

\begin{tabular}{|c|c|c|c|}
\hline INDICATORS & MAJOR CHANGES & MINOR CHANGES & NO CHANGE \\
\hline \multicolumn{4}{|c|}{ Exterior Architectural Features } \\
\hline Shape and Size & $\begin{array}{l}\text { A complete re-configuration of external } \\
\text { shape, form and size of the building }\end{array}$ & $\begin{array}{l}\text { Slight change to the size of the } \\
\text { building but retaining the external } \\
\text { shape or form of the building }\end{array}$ & $\begin{array}{l}\text { No change to the building size, } \\
\text { shape or form }\end{array}$ \\
\hline Camp Layout & Different layout of homestead & $\begin{array}{l}\text { A mix of new and old layout of } \\
\text { homestead }\end{array}$ & $\begin{array}{l}\text { Same homestead layout } \\
\text { retained }\end{array}$ \\
\hline
\end{tabular}




\begin{tabular}{|c|c|c|c|}
\hline INDICATORS & MAJOR CHANGES & MINOR CHANGES & NO CHANGE \\
\hline \multicolumn{4}{|l|}{ Building Construction } \\
\hline Foundation types & $\begin{array}{l}\text { Entirely new foundation type or new } \\
\text { technique of constructing foundations }\end{array}$ & $\begin{array}{l}\text { A mix of new and old foundation } \\
\text { types and construction techniques }\end{array}$ & $\begin{array}{l}\text { No variation in foundation type } \\
\text { or in the construction } \\
\text { techniques }\end{array}$ \\
\hline Basic building principle & $\begin{array}{l}\text { Entirely new principles on which } \\
\text { buildings are built }\end{array}$ & $\begin{array}{l}\text { Slight variation in basic building } \\
\text { principle }\end{array}$ & $\begin{array}{l}\text { Same building principle } \\
\text { retained }\end{array}$ \\
\hline Difference in order of building tasks & $\begin{array}{l}\text { Different set of tasks in the building } \\
\text { construction process }\end{array}$ & $\begin{array}{l}\text { Same set of tasks but change in the } \\
\text { sequence during building process }\end{array}$ & $\begin{array}{l}\text { No change in the sequence of } \\
\text { building tasks }\end{array}$ \\
\hline \multicolumn{4}{|l|}{ Spatial Configuration } \\
\hline Spatial arrangement within building & $\begin{array}{l}\text { Outright addition of entirely new space } \\
\text { or removal of existing space within } \\
\text { building }\end{array}$ & $\begin{array}{l}\text { Adaptation of existing space with } \\
\text { modifications for different use } \\
\text { within building }\end{array}$ & $\begin{array}{l}\text { No change made to spatial } \\
\text { arrangement within building }\end{array}$ \\
\hline $\begin{array}{l}\text { Arrangement of building units within } \\
\text { homestead }\end{array}$ & $\begin{array}{l}\text { A complete change in the arrangement } \\
\text { of units in the homestead }\end{array}$ & $\begin{array}{l}\text { Slight change in the arrangement } \\
\text { of buildings units within the } \\
\text { homestead }\end{array}$ & $\begin{array}{l}\text { No change in the arrangement } \\
\text { of building units within the } \\
\text { homestead }\end{array}$ \\
\hline
\end{tabular}

Table 2. Differences in wall cladding materials and techniques in base camp dwellings.

\begin{tabular}{llll}
\hline Cladding Materials & Laying Technique & Bayelsa State & Bakassi Peninsula \\
\hline \multirow{2}{*}{ Matted Raffia Palm leaves } & Vertical & $\sqrt{ }$ & $\sqrt{ }$ \\
& Diagonal (cross-striated) & $\sqrt{ }$ & $\sqrt{ }$ \\
Whole Raffia Palm Fronds & Horizontal & $\sqrt{ }$ & $\sqrt{ }$ \\
Wooden Planks: & Laid Horizontally & $\sqrt{ }$ & \\
Palm Frond Stems: & Laid Vertically & $\sqrt{ }$ & \\
\hline
\end{tabular}

\subsubsection{Fenestrations}

In both Bayelsa and Bakassi, the base camp dwelling is built without the inclusion of windows or window openings. This is mainly because the materials used for wall cladding are arranged together to allow for the flow of air into the building. A main entrance opening is usually located on the longer side of the building and occasionally a narrower exit from the hearth space is also created. The opening in the hearth space serves as a smoke outlet. In other cases, the sides of a gable roof are left uncladded to act as smoke outlets as well (figure 15). Also, in both the Bayelsa and the Bakassi models, no doors are used to secure the entrance and exit openings or the other openings that serve as access into the sleeping areas (figure 9). What little level of privacy the households require is usually achieved by covering such openings with curtains made out of a large piece of cloth normally worn by women, or large polythene sheets used in wrapping fish meant for sale (figures 9-10). The large piece of cloth is also used in covering openings or access to sleeping areas within the dwelling. One of the reasons openings are not secured in base camps is because of a strict behavioural code that has been maintained through the generations in the base camps.

\subsubsection{Roof Types, Materials and Techniques}

Roofing types used in both Bayelsa state and Bakassi peninsula are predominantly thatch. Corrugated roofing sheets made from zinc is also used but for non-residential buildings such as worship halls, primary schools and other communal buildings, in both inshore base camp dwellings and offshore season dwellings. The technique employed in the production of thatch roofs is similar to that used in producing vertically striated wall claddings from the raffia palm leaves. This is known as matting. Sometimes the sides of the roof are left open and this can serve as smoke exits. At other times the sides are completed covered with cladding material. A summary of the different roof types, roofing materials and techniques are listed in table 3 .

Table 3. Differences in roofing techniques and materials used in base camp dwellings.

\begin{tabular}{lll}
\hline Roof Types & Bayelsa State & Bakassi Peninsula \\
\hline Gable roof with open sides & $\sqrt{ }$ & $\sqrt{ }$ \\
Gable roof with side cladding & $\sqrt{ }$ & $\sqrt{ }$ \\
Roofing Techniques & & $\sqrt{ }$ \\
Extended eaves & $\sqrt{ }$ & $\sqrt{ }$ \\
Short eaves & & $\sqrt{ }$ \\
Roofing Materials & $\sqrt{ }$ & \\
Thatch roofs: Matted Raffia Palm Leaves & & \\
Corrugated roofing sheets: Zinc & & \\
\hline
\end{tabular}




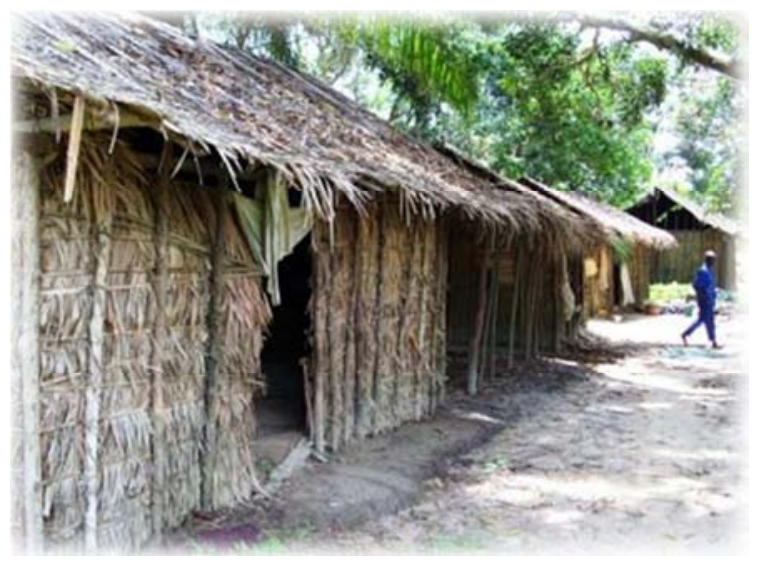

Figure 9. Main entrance opening with cloth used as curtain.

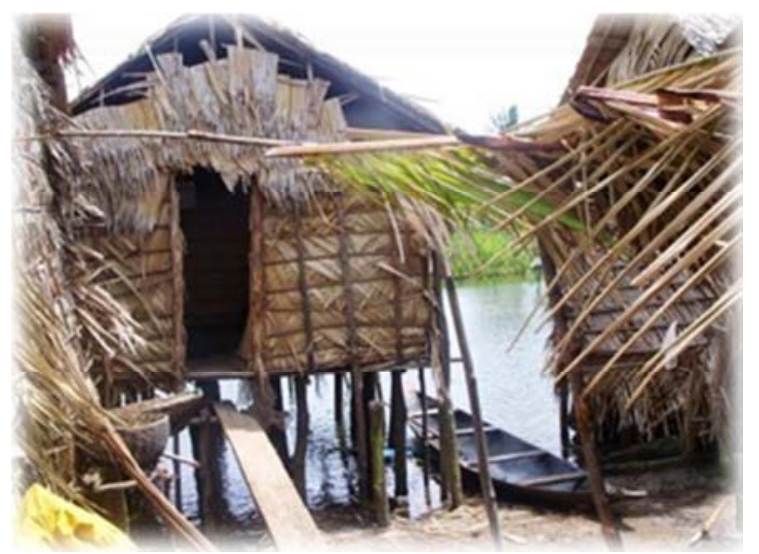

Figure 10. Main entrance just left open.

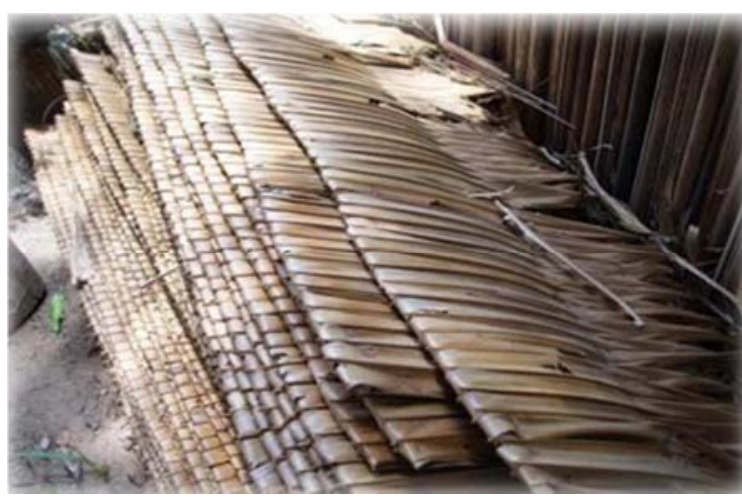

Figure 11. Dried matted thatch.

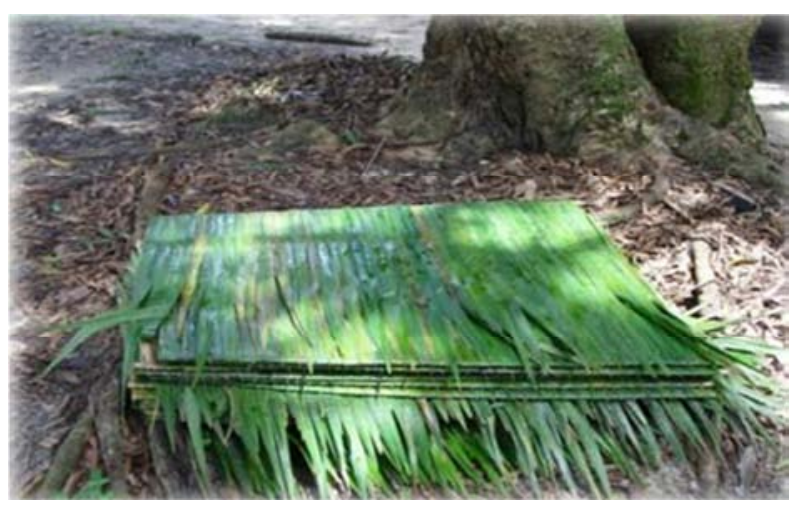

Figure 12. Freshly matted thatch.

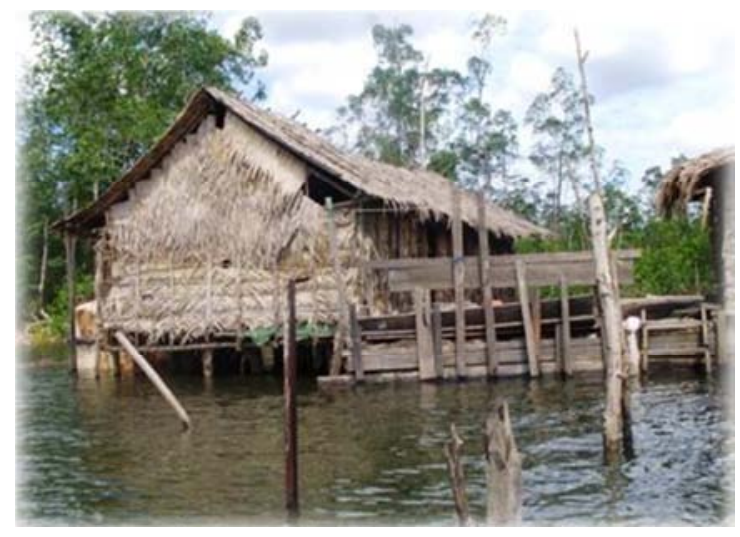

Figure 13. Gable roof with closed sides (BoroFishing camp, Bakassi)

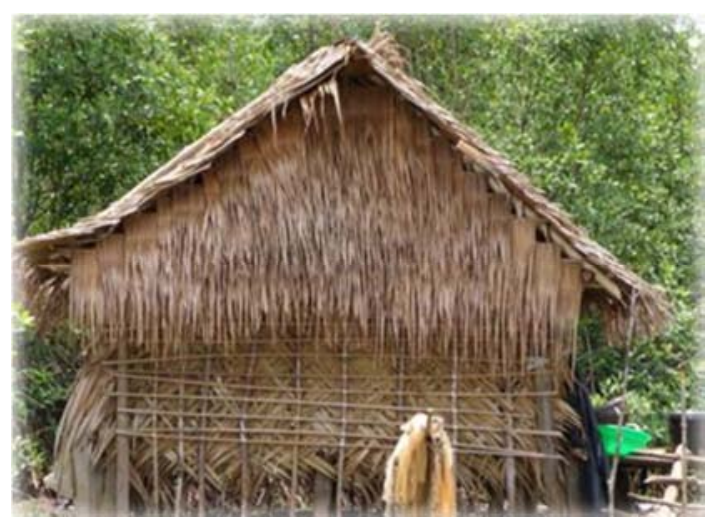

Figure 14. Gable roof with closed sides (New Year base camp, Bayelsa).

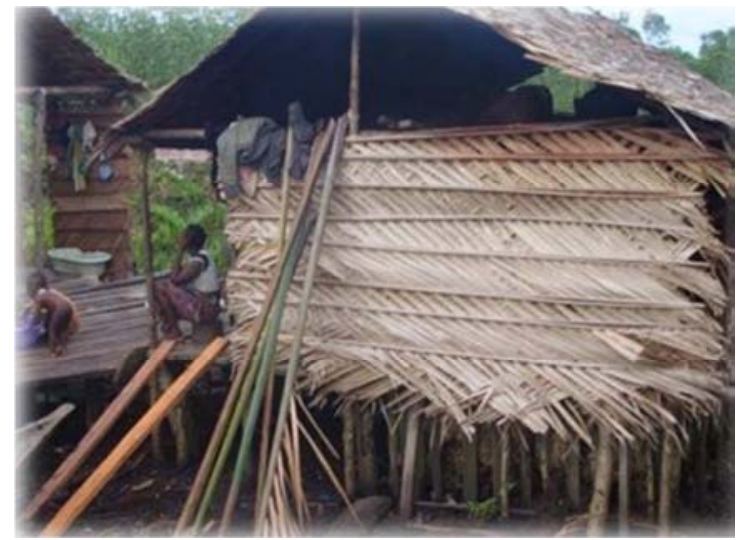

Figure 15. Gable roof with open sides (Jaja base Camp, Bakassi)

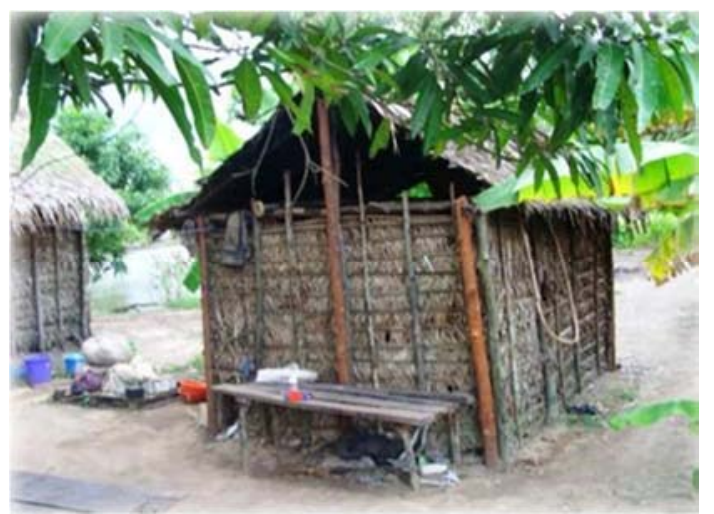

Figure 16. Gable roof with open sides (Nigeriaware base camp, Bayelsa). 


\subsubsection{Materials and Techniques Used for Embankments}

Due to the scarcity of dry elevated land in the mangrove swamps, methods have been developed to claim much needed elevated landed space from the marshland and surrounding water. The chikoko mud, which is resilient to the wearing effects of flowing water is gathered into the selected area and stamped down for compression. The mud is however kept within the designated space and the water kept out, by means of wooden structures that serve as embankments. Variations have been observed in the techniques with which these wooden structures are placed and the form in which these structures are used, between the migrant fishing settlements in Bayelsa and Bakassi.

Table 4. Techniques and materials used for embankments in base camp dwellings.

\begin{tabular}{lll}
\hline & Bayelsa State & Bakassi Peninsula \\
\hline $\begin{array}{l}\text { Techniques and Materials } \\
\text { used for Embankments }\end{array}$ & Whole logs of wood laid horizontally and supported by & Several wooden stakes placed vertically or horizontally in close \\
vertical stakes placed in wide intervals externally & intervals and supported with slim wooden poles externally \\
\hline
\end{tabular}

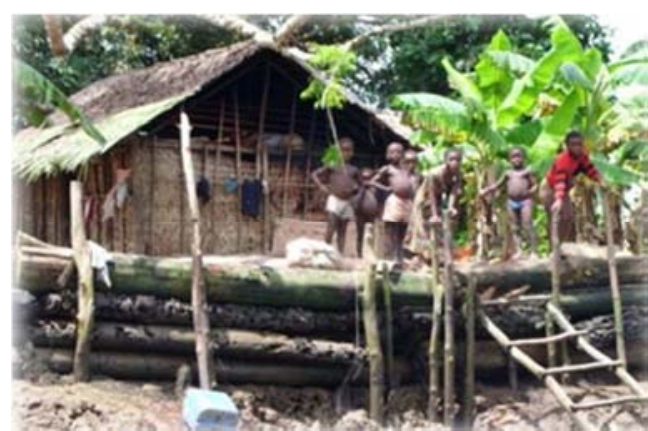

Figure 17. Embankments for reclaimed land space (Sulekiri base camp, Bayelsa).

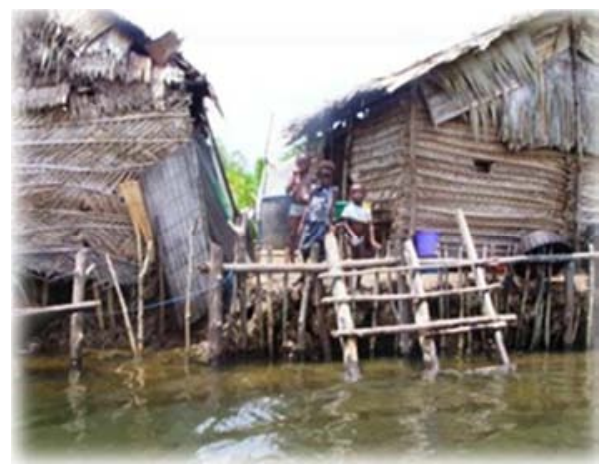

Figure 18. Embankments for reclaimed landspace (Temekiri zion base camp, Bakassi).

\subsection{The Building Construction Process}

In both locations, construction can be by communal or by individual effort. The communal process usually occurs in multi-homestead camps and requires the participation of all the neighbouring household heads as well as other males in the camp. The owner is often expected to source for the building materials and with this method, the build is faster. The individual process is when all aspects of the construction are carried out entirely by the intended user. Another constant attribute that can be identified in both societies, is construction based on the same basic principle on which the buildings are built, which is the simple post and beam system. Furthermore, the foundations required for the three types of gbene ware, is also another constant attribute found in both migrant fishing societies. But the focus here is the step-by-step process or the sequence of tasks that make up the building process of the base camp dwelling's superstructure.

The comparison is drawn from the narratives given by respondents in Bayelsa State and their counterparts in the Bakassi peninsula, on the various tasks that make up the building process. The process was broken down into logical steps or specific tasks by both groups of fishermen interviewed. It is these steps that will be compared in table 5 to see if variations exist in the construction process of the dwelling, in the two societies.

Table 5. A comparison of the sequence of tasks in the building process in Bayelsa and Bakassi.

\begin{tabular}{|c|c|c|}
\hline $\begin{array}{l}\text { Sequence of } \\
\text { Building Tasks }\end{array}$ & Bayelsa & Bakassi \\
\hline 1 & Main structural frames made from Iron wood (Ikoki) erected & Main structural frames made from Iron wood (Ikoki) erected \\
\hline 2 & Main beams serving both as Lintels and Wall plates (Ware Som) & $\begin{array}{l}\text { Construction of door frames } \\
\text { (Ware bubou tein) }\end{array}$ \\
\hline 3 & Placing of the sub beams on top of the wall plates (Imgbere) & $\begin{array}{l}\text { Installation of main beams serving both as lintels and wall plates } \\
\text { (Ware Som) }\end{array}$ \\
\hline 4 & Roof frames are constructed on which the ridge is placed $(\mathrm{Za})$ & $\begin{array}{l}\text { Placing of the sub beams on top of the wall plates, sub beams } \\
\text { also used to demarcate room spaces (Imgbere) }\end{array}$ \\
\hline 5 & Rafters are constructed and installed (Ibamea) & King posts are raised (Ogbonoba) \\
\hline 6 & Roofing purlins are put in place (Izenseri) & Roof frames are constructed on which the ridge is placed $(Z a)$ \\
\hline 7 & $\begin{array}{l}\text { Laying the thatch (Akain) on the roof frame (Ware you) combined } \\
\text { with roof side cladding }\end{array}$ & Rafters are constructed and installed (Ibamea) \\
\hline 8 & Installing timber to hold down the thatching (Tutere tein) & Roofing purlins are put in place (Izenseri) \\
\hline 9 & Cladding of external walls with cane or matted raffia (kigi) & Laying the thatch (Akain) on the roof frame (Ware you) \\
\hline 10 & Laying of wooden floors (Agbada) or stamping mud floor (Atou) & Installing timber to hold down the thatching (Tutere tein) \\
\hline 12 & & Roof side cladding \\
\hline 13 & & Laying of wooden floors (Agbada) or stamping mud floor (Atou) \\
\hline 14 & & Construction of drying stack (Eri) and other furniture \\
\hline
\end{tabular}


Comparing the logical sequence of tasks undertaken during the construction of the base camp dwelling has revealed a number of changes in the construction process in both societies. Firstly, construction of the base camp dwelling in the Bakassi Peninsula requires three additional tasks, not included as distinct tasks in the building process in Bayelsa.

The tasks in this case have been highlighted in table 5. Steps two and five in the building process in Bakassi indicate that the construction of door frames after erection of the main structural frames and the raising of the king posts are regarded as two distinct stages in the construction process. The length of king posts determines the height of the roof and these have to be measured to the standard 6.5 feet (ken agbobu ken akpala mo) before cutting. However this standard is fairly flexible. This is not the case in Bayelsa as both steps are not included in the construction process. Lastly, In Bayelsa, the task of cladding the roof side is combined with the task of laying the thatch, which is the $7^{\text {th }}$ in the sequence. However, in Bakassi, this is an entirely different task undertaken only after the external walls have been clad. It usually occurs towards the end of the build (Step 12) in construction process. These changes that have been identified in the building process of the base camp model in Bakassi indicate that some minor variations have occurred in this aspect of building culture over the years. Figure 19 shows the different building components, height and spacing dimensions.

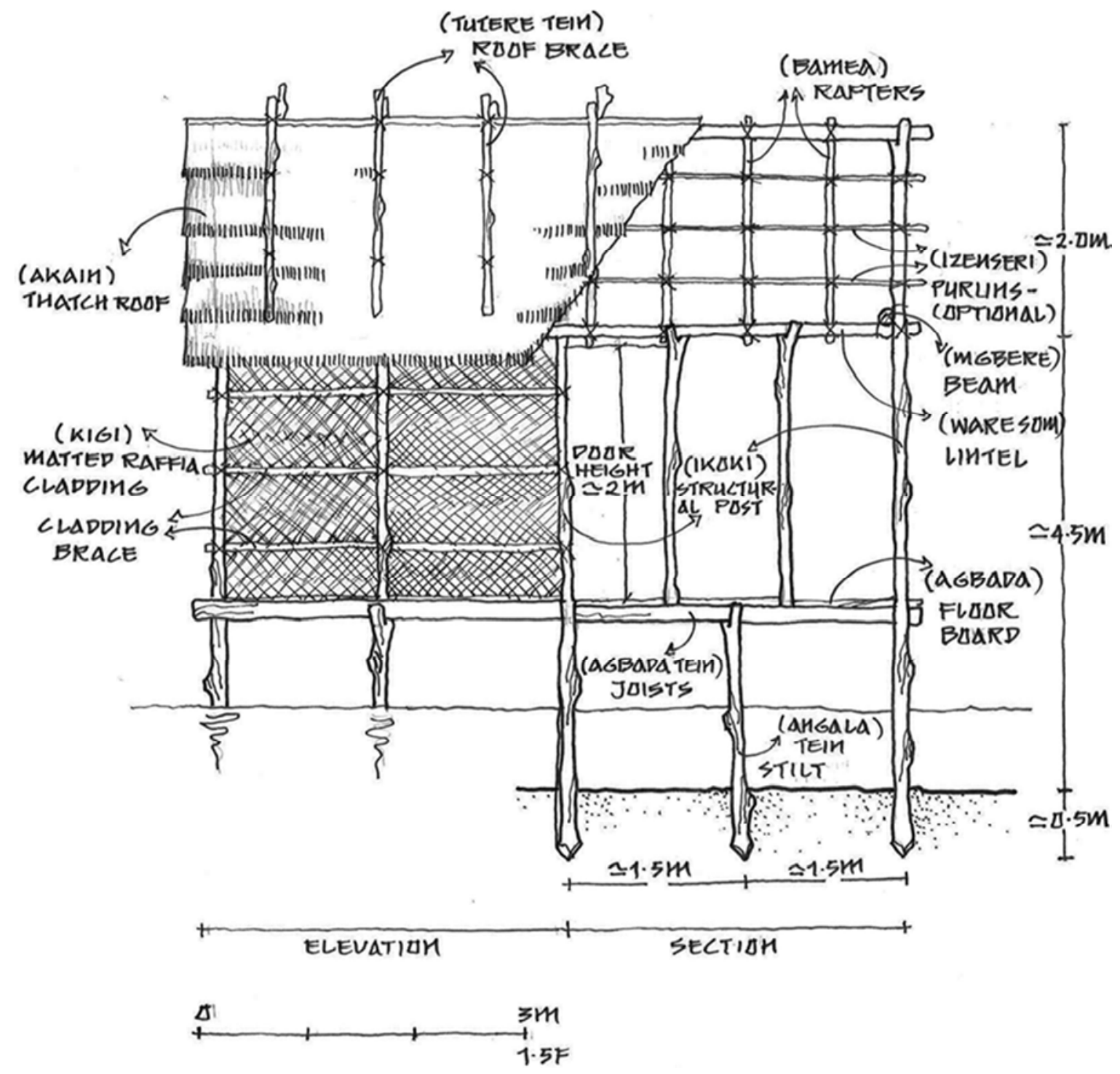

Figure 19. Building components with labels and standard dimensions.

\subsection{Spatial Configuration}

The study reveals two aspects to spatial configuration in base camp dwellings. The first is the arrangement of spaces within the dwelling and then the arrangement of dwelling units within the base camp homestead.

\subsubsection{Bathing Area - Benibiriware}

In Ijo communities in Bayelsa, communal bathing at the river front in the morning, is common practice for rural dwellers and forms part of their regular social activities. It has been carried on through the generations and reflects 
communal homogeneity. Swimming or simply dipping in the river is the most common method of washing off soap lather. Sections of the river front are earmarked for bathing according to gender and age with considerable distance maintained between both sexes. Being comfortable enough to undress amongst non-relatives is also indicative of familiarity of persons in a close-knit rural community.

In Bakassi, bathing is carried out in concealed purposebuilt spaces in base camps. Examples of open-roofed bathing spaces detached from the main dwelling units in Bakassi are shown in figures 20 and 21 below. Only bathing is carried out in these spaces, defecation is carried out in the mangroves further behind the dwelling area.

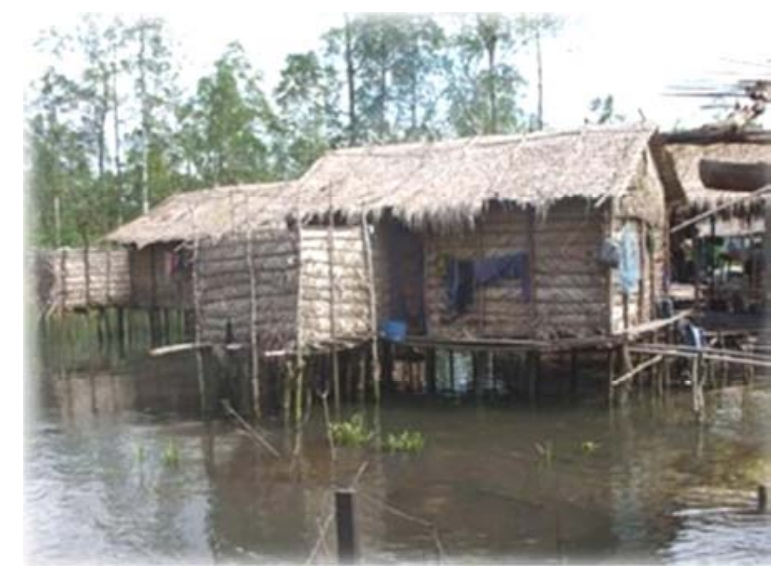

Figure 20. Detached bathing spaces in Borogbene Base Camp in Bakassi.

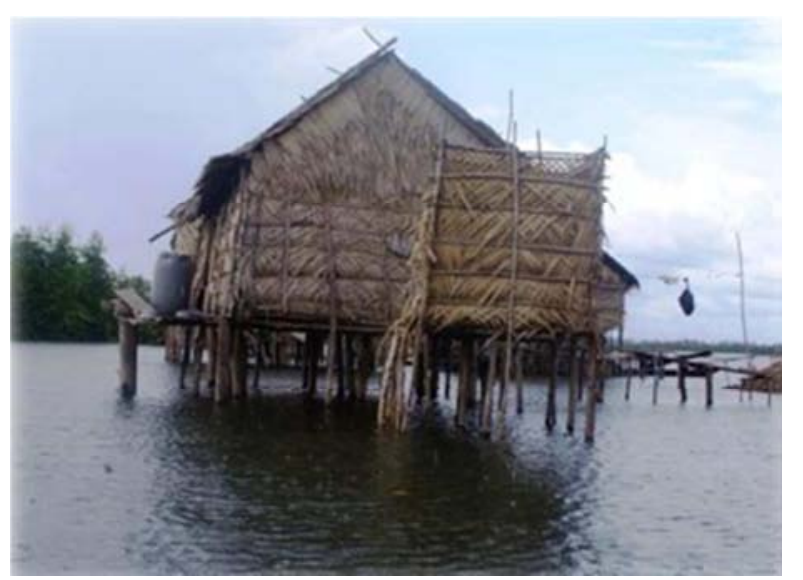

Figure 21. Bathing space in Tubogbene base camp in Bakassi.

\subsubsection{Daytime Rest Area-Atele}

The feature whose absence is most pronounced from the Bakassi model of the base camp dwelling but, which forms part of the culture core spaces in the Bayelsa model is the atele. In communities within the Bayelsa region every compound, which is a combination of several homesteads belonging to members of the same extended family, have an 'atele'. This is the family rest house and a place for socialising. The 'atele' is often located strategically to capture views of the scenery, air flow, and to see and greet passersby. Traditionally, it is used as a place where issues are tabled and discussed by the men of the compound or fishing camp and normally during the day. This cultural practice has evidently being carried on from the village into life in the fishing camp, in the regions around Bayelsa State. The data shows that all multi-homestead fishing camps used as case studies in Bayelsa State, have at least one 'atele' (see figure 22). But the data also shows that although this is a core cultural feature in Bayelsa, it is one of the features that is conspicuously absent in the Bakassi model of the base camp.
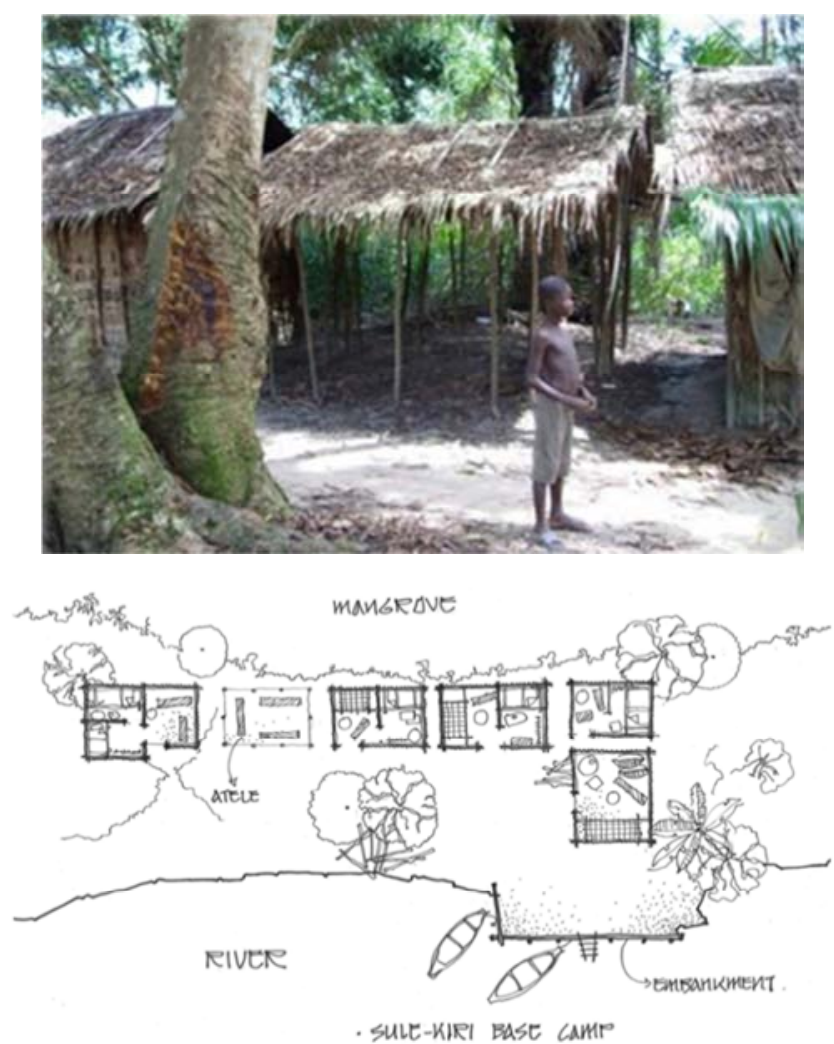

Figure 22. Atele space and sketch showing position of the atele in Sulekiri base camp (Bayelsa).

\subsubsection{Living Area - Warekiri}

The living area (warekiri) is another new addition to the base camp model in Bakassi, not previously treated as a distinct space in the Bayelsa model. The addition of this space to the model in Bakassi appears to be the way of creating a space in the camp that is similar in some of its functions to the atele, in terms of providing a space for entertaining visitors, relaxation and holding family talks with other kinsmen. It also has the added advantage of being a space for eating and carrying out some household chores. But the main difference between the warekiri and the atele is that, while the atele is detached from the main dwelling unit and is used only by men in the Bayelsa model, the warekiri space is attached to the main dwelling unit in the Bakassi model and can be used by all members of the family. Also, the atele is not a space for eating, except in situations where meals are served after undertaking communal labour in the construction of a new building in the camp. In such cases the member whose dwelling is being constructed provides the meal for all the other camp members involved in the building project. Examples of how the warekiri is used are seen in figures 23-24 below. 


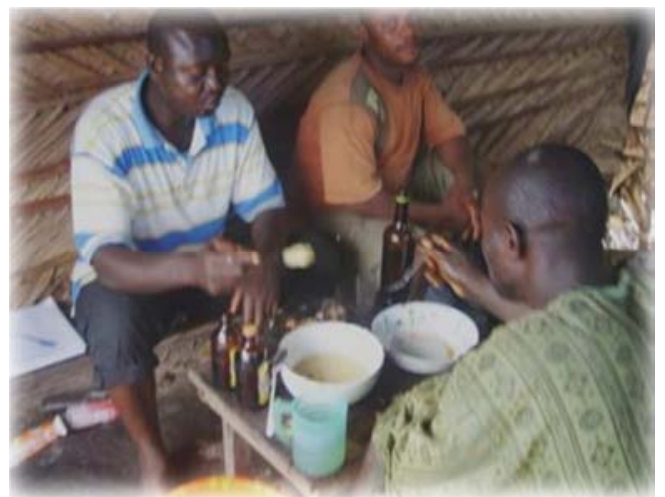

Figure 23. Two household heads and the research Guide eating in the warekiri (Ijo creek, Bakassi).

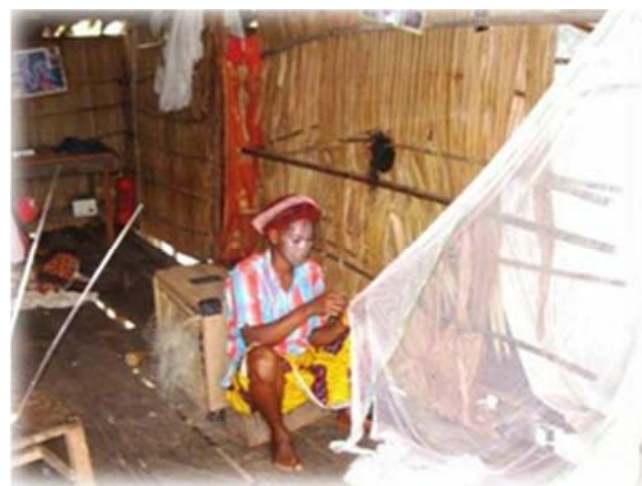

Figure 24. Mending mosquito net in the warekiri (Oyegbene basecamp, Bakassi).

\subsubsection{Size of Building Units}

The addition of the living room or warekiri space to the sleeping areas, in order to create a single building unit is a major contributing factor to the overall increase in the size of the Bakassi model. This makes the Bakassi model larger in size than the Bayelsa model, especially since the sleeping area in the Bayelsa model is often merged with the hearth space, which effectively makes the size of the building model smaller than it would have been if the sleeping and hearth spaces were separated. This variation in the size of the building units due to the merging or separating of spaces stems from diverging opinions about the proximity of sleeping and hearth spaces in the base camps. From the interview responses in Bayelsa, the merging of the sleeping and hearth spaces was due to the need for constant monitoring of the fish drying process. In Bakassi on the other hand, the general consensus on why the spaces are separated is due to the perceived fire risk of having open fire places surrounded by combustible material, close to sleeping areas. This concern can be best summarized in this statement given below,

The main building is separated from the area where we cook and dry the fish because of fire. We build it like this to avoid any fire incidence...so that if there is fire at least it will not affect the main house where the family is staying. This is how we have always been building it.

(Interview April 2008: Household head - Jaja 2 fishing camp, Bakassi)

This suggests that the variation in the size of the two models results from two different ideas behind the proximity of two core spaces in the respective locations. While one society considers the issue of constant monitoring, the other focuses on health and safety. These ideas have both being translated into built forms resulting in the ensuing differences between models.

\subsection{Arrangement of Dwelling Units Within the Base Camp Homestead}

\subsubsection{Layout of Dwellings Indicating Kinship/Non-Kinship Ties}

Another major change in the layout of the camp dwellings in Bakassi is the inclusion of features that indicate kinship ties amongst households in multi-homestead base camps. These are base camps occupied by members of the same family such as parents and children, siblings and cousins. The use of raised walkways connecting different building units and the sharing of the hearth space are the two ways kinship ties are indicated and reinforced in multi-homestead camps in Bakassi. In some cases, hearth spaces are shared alongside the use of connecting walkways. In the few cases where connecting walkways were not used in such camps, it was discovered that a single hearth space was often shared by all the households in the camp. In such cases, the hearth space was centrally located so it could be easily accessible to all the households using it. This form of camp layout, in which walkways are used or hearth spaces are shared is only present among migrant fishing camps in Bakassi and not in Bayelsa.

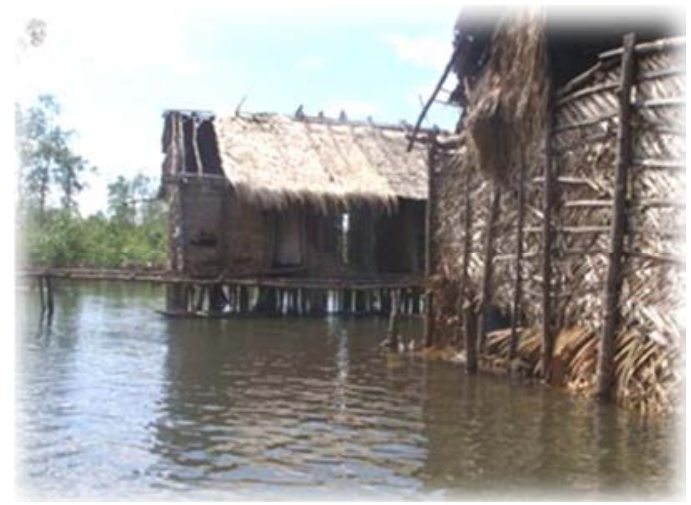

Figures 25. Walkways connecting two households in Davidbgene and Oyegbene base camps (Bakassi).

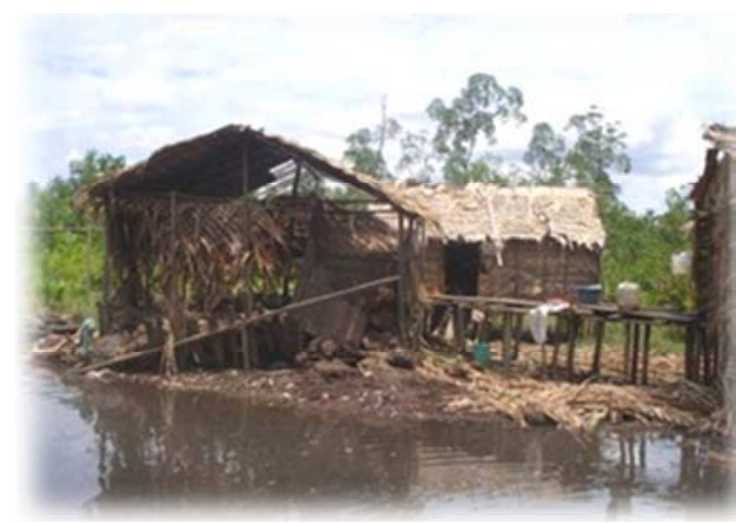

Figures 26. Walkways connecting two households in Davidbgene and Oyegbene base camps (Bakassi). 


\subsubsection{Arrangement of Building Units Within Homesteads}

The physical planning of the base camp refers to the arrangement of building units and other features in relation to each other as well as the main river access into the camp site. There are two ways in which in the arrangement of units within the homestead will be discussed in this study. The first is the arrangement of units in a multiple homestead camp, while the second is the arrangement of units in a single homestead camp. The arrangement of units in multihomestead camps suggests which building units belong to a particular household in the camp. There are significant variations in the planning pattern of multi-homesteads in Bayelsa and Bakassi.

In multi-homestead camps, buildings can be either randomly arranged or arranged in a specific order. For example, in the Bayelsa model the position of the camp founder's homestead on site, indicates the point where the direction of expansion of the camp starts. The next member joining the camp builds next to the founder's dwelling and whichever direction is chosen, sets a precedent for all subsequent members to follow. But even if dwellings are built following this pattern, the units are often built close together such that one cannot tell the units of the different households in the camp apart. The floor plans show the use of connecting walkways for units belonging to specific households in Bakassi. The use of connecting walkways in this case differs from its use as a kinship indicator in multihomestead camps. The difference is in the scope in which it is used. Where the use of walkways as a kinship indicator connects the dwellings of two or more individual households; its use in planning simply connects building units of one household, either in a single or multi-homestead camp with non-kin members.

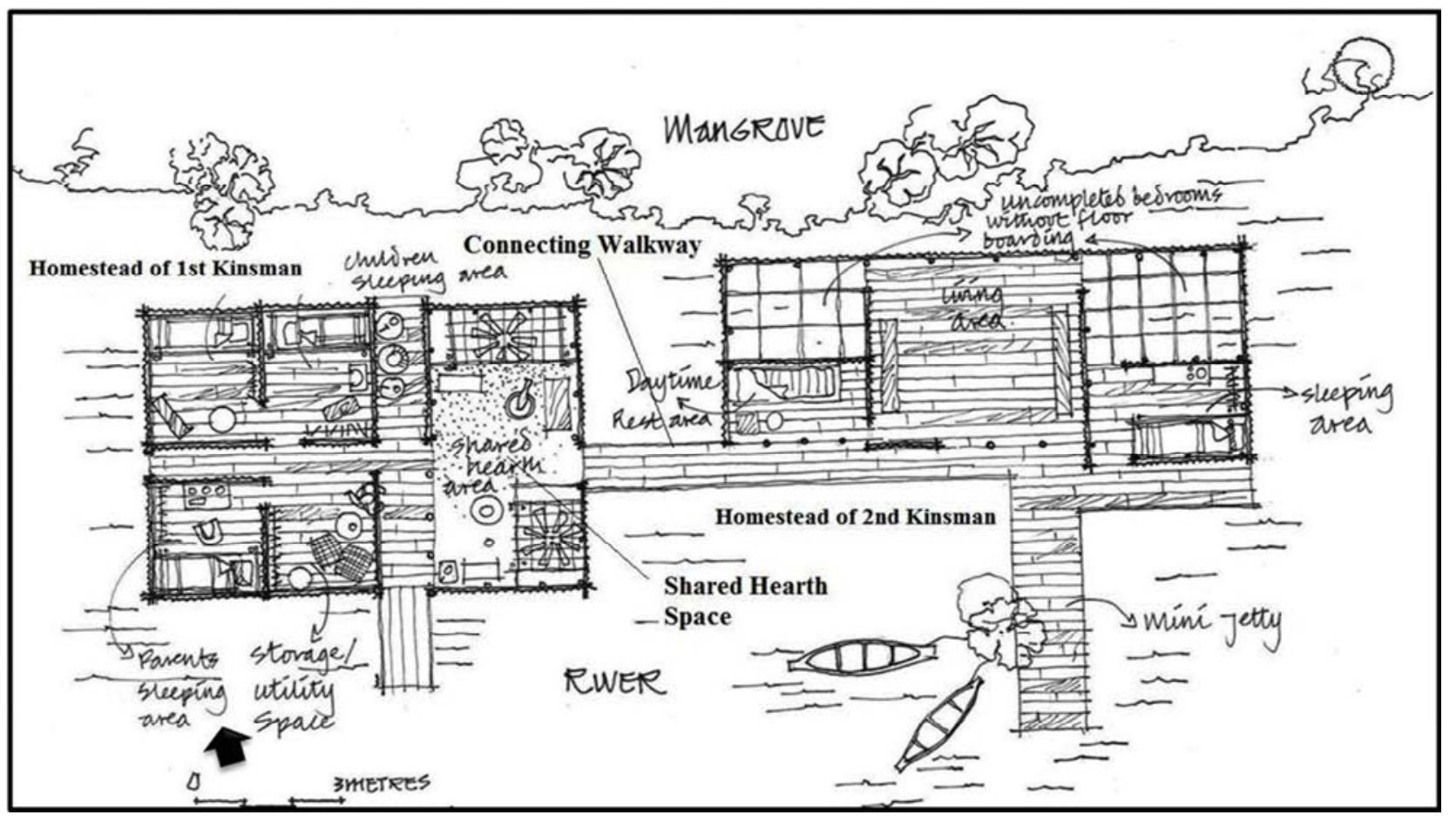

Figure 27. Connecting walkway and shared hearth space in Ijo Creek extension, Bakassi.
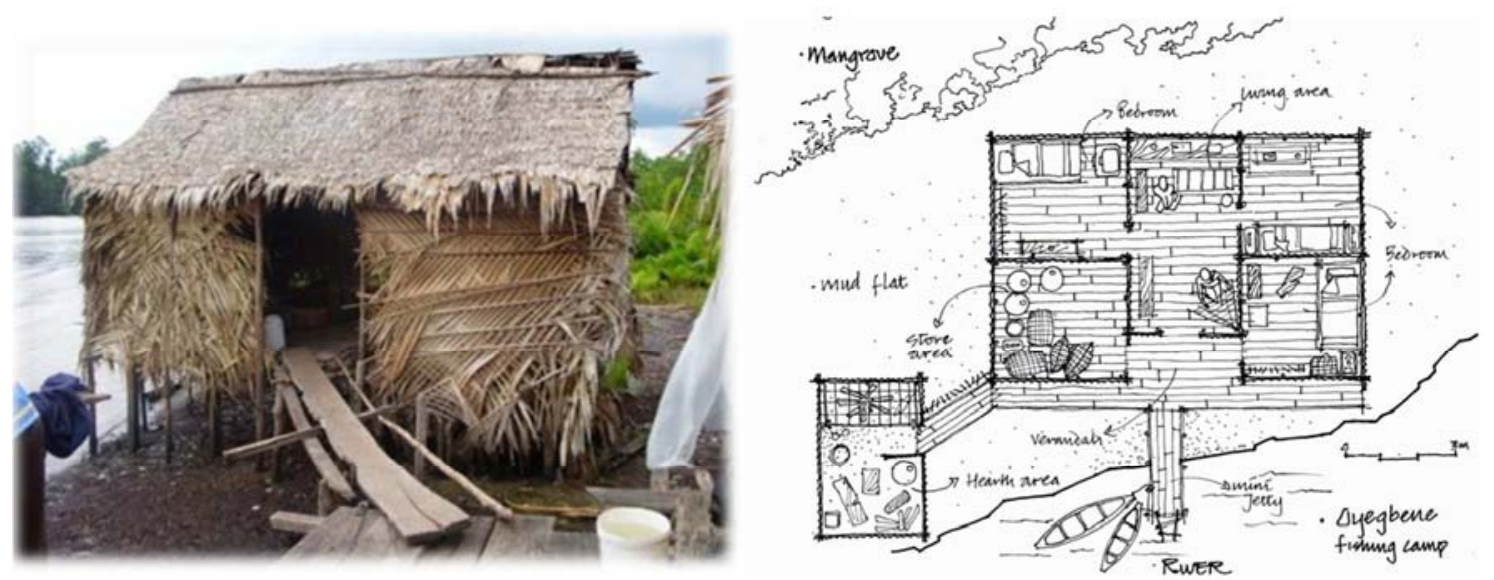

Figure 28. Raised walkway connecting separate units in Oyegbene base camp, Bakassi. 


\section{Results and Analysis}

The results show that the changes occurred only in certain aspects of the base camp architecture, and not in others. However, the changes differ in levels as indicated in table 6. The reason for categorizing change is to give an indication of the extent of similarities as well as the differences between the two design models. This emphasizes the fact that both dwelling models are of similar origins, which then justifies the search for variations that may have occurred between them over time.

Table 6. Summary of levels of changes in different aspects of the migrant fisher architecture.

\begin{tabular}{|c|c|c|c|c|c|}
\hline \multirow{2}{*}{ Indicators } & \multicolumn{2}{|l|}{ Major changes } & \multicolumn{2}{|l|}{ Minor changes } & \multirow{2}{*}{ No Change } \\
\hline & Bayelsa & Bakassi & Bayelsa & Bakassi & \\
\hline \multicolumn{6}{|c|}{ Exterior Architectural and surface Features } \\
\hline Shape and Size & & & Rectangle & $\begin{array}{l}\text { Larger sized } \\
\text { Rectangle } \\
\sqrt{ }\end{array}$ & \\
\hline Camp Layout & $\begin{array}{l}\text { No use of walkways } \\
\text { and no sharing of } \\
\text { hearth space to } \\
\text { indicate kinship ties }\end{array}$ & $\begin{array}{l}\text { Walkways and } \\
\text { shared hearth } \\
\text { space used to } \\
\text { indicate kinship } \\
\text { ties } \sqrt{ }\end{array}$ & & & \\
\hline Traditional Building Materials & & & $\begin{array}{l}\text { Three types of wall } \\
\text { cladding materials }\end{array}$ & $\begin{array}{l}\text { One type of wall } \\
\text { cladding material } \\
\sqrt{ }\end{array}$ & \\
\hline \multicolumn{6}{|l|}{ Building Construction Process } \\
\hline Foundation types & & & & & $\begin{array}{l}\text { No variation in } \\
\text { foundation type or in the } \\
\text { construction techniques }\end{array}$ \\
\hline Basic building principle & & & & & $\begin{array}{l}\text { No variation in basic } \\
\text { building principle }\end{array}$ \\
\hline $\begin{array}{l}\text { Difference in order of building } \\
\text { tasks }\end{array}$ & & & $\begin{array}{l}11 \text { steps used in the } \\
\text { construction } \\
\text { process }\end{array}$ & $\begin{array}{l}14 \text { steps used in the } \\
\text { construction process } \\
\sqrt{ }\end{array}$ & \\
\hline \multicolumn{6}{|l|}{ Spatial Configuration } \\
\hline $\begin{array}{l}\text { Spatial arrangement within } \\
\text { building }\end{array}$ & $\begin{array}{l}\text { Merging of hearth } \\
\text { and sleeping space }\end{array}$ & $\begin{array}{l}\text { Addition of } 2 \text { new } \\
\text { spaces. Separation } \\
\text { of hearth and } \\
\text { sleeping space } \\
\sqrt{ }\end{array}$ & & & \\
\hline $\begin{array}{l}\text { Arrangement of building units } \\
\text { within homestead }\end{array}$ & $\begin{array}{l}\text { No connection of } \\
\text { separate household } \\
\text { units in base camp }\end{array}$ & $\begin{array}{l}\text { Connection of } \\
\text { separate } \\
\text { household units in } \\
\text { base camp } \\
\sqrt{ }\end{array}$ & & & \\
\hline
\end{tabular}

In table 6 , a detailed description of the various minor and major changes that exist between the dwelling models in Bayelsa State and the Bakassi Peninsula are given, but also included are the aspects of the built form where no change was identified.

The summary shows that of the nine attributes that categorise different aspects in architecture and building culture, in which changes are likely to occur, different levels of change identified are as follows:

Major change was indicated in three aspects of the architecture

Minor changes were identified in three aspects

Three attributes of the architectural models showed no notable signs of change between both societies.

This suggests that in total the original model in Bayelsa has undergone some level of change over the years, from what it was, to what can now be regarded as the Bakassi model of the base camp dwelling. These changes when combined constitute variations in the base camp architecture of Ijo migrant fishermen.

\section{Discussion}

The study aimed at examining the dwelling designs of the fishing communities in two different locations, in search of differences that may have occurred between them, through the accumulation of changes over time. The idea that changes exist follows the theory of cultural dynamism, of which every cultural sub-system yields to change whether by internal forces or by external influence. But it remains to see if the series of change experienced over time as resulted in any significant variations. Empirical evidence from exterior evaluation and case study analysis shows that there are variations between the base camp dwellings of Ijo migrant fishermen in Bakassi and in Bayelsa. However, the aspects of major change that contributed to these variations were observed mainly in spatial re-arrangements, retention and removal.

Some findings from similar studies suggest that not 
every change in built form is caused by a corresponding change in social behaviour [17]. Others are of the opinion that spatial transformations of dwellings of a group in two different locations "interrelate with the changing categories and perceptions of the world", which the group undergoes while living away from the ethnic homeland [18]. There are also others who infer that change in the design and use of domestic space is related to a matrix of factors and not just one. As such no individual behavioural factor can explain change but an agglomeration of these factors can ultimately influence change. Especially when it concerns change in spaces associated with the preparation and eating of food.

\section{Conclusions}

But from findings in this study, the conclusions derived were that spatial design of base camp dwellings in Bakassi, have evolved cognitively to accommodate the changing social disposition of the Ijo migrant fishermen. This is because variations between the dwelling models related more to social behaviour, of which privacy in bathing, socialization and kinship ties and separation of work (food preparation and processing) and rest spaces were paramount.

With regards to kinship relations, the study shows that effort is made to emphasize and possibly strengthen kinship ties in the Bakassi model through base camp design and planning. This entails the inclusion of connecting walkways as a form of social support. Researchers have argued that such actions are connected to issues of migrants maintaining their cultural identity amongst other groups in areas to which they have migrated, especially among migrants who practice long-term or permanent migration $[18,19]$. But the research shows that besides the cultural identity agenda, the use of connecting walkways in Bakassi for immediate family members, suggests more of family inter-dependence and solidarity, as well as ease of movement between homesteads.

Although the responses from interviews do not specify the exact reasons for walkways, the sharing of hearth spaces and equipment amongst families is part of the Ijo culture. However, the use of walkways groups homesteads together and gives an impression that the different units are all part of a single large homestead. This suggests to other neighbouring groups that the family in question is large and has strength in numbers. This illusion of strength and numbers may be necessary since the fishermen live away from home and are surrounded by other groups, some of which are known to have histories of conflicts with Ijos. This supports the idea that such a cluster of buildings, though rectangular yet nomadic "indicate the presence of nucleated settlements" whose main advantage is their "defence and production capabilities" [18].

\section{Recommendations}

As seen from this research, a lot can be learned from the study of social change reflected in architecture over time and space. This research focuses on architectural variations as a result of social change between migrant fisher dwellings in Bayelsa and Bakassi however, bearing in mind that the scope of the data for investigating causes of variations were based on external architectural features. As such, the scope of this study can be expanded to include internal features and arrangements. It can also be expanded to include studies on variations in other countries where Ijo fishermen are present such as; Benin republic, Equatorial Guinea, Gabon, the Republic of Congo and the Lake Chad regions.

\section{References}

[1] Randall, S. (2005) Review of Literature on Fishing Migrations in West Africa - From a Demographic Perspective.

[2] Njock, J. C. and Westlund, L. (2008) 'Understanding the Mobility of Fsihing People and the Challenge of Migration to Devolved Fisheries Management', in Westlund, L., Holvoet, K. and Kebe, M. (eds) Achieving Poverty Reduction through Responsible Fisheries: Lessons from West and Central Africa. Food and Agriculture Organisation.

[3] Olawepo, R. A. (2008) 'Using Participatory Rural Appraisal to explore coastal fishing in Badagry villages, Nigeria', Environmentalist, 28, pp. 108-122.

[4] De Koning, R. (2008) Bearing the Bakassi: Local livelihoods and natural resource management under military stalemate, Yaounde, Cameroon: CIFOR - Center for International Forestry Research.

[5] Agoro, S. N. A, Asuk, C, Olali, S. T and Etekpe, A. (2009) The Ijo in West and Central Africa, In The Izon of the Niger Delta, Alagoa (eds) Onyoma Research Publications. PortHarcourt: Nigeria.

[6] Brisibe, W. G. (2016) Base Camp Architecture: examining variations in fisher dwellings in Nigeria and Cameroon, Sage Open (January - March Issue) pp 1-15, DOI: 10. $1177 / 2158244016636942$.

[7] Brisibe, W. G. (2016b) Assessing Variations in Ijo Migrant Fisher Architecture through Spatial Classification, Space and Culture, pp 1-30, DOI: 10. 1177/1206331216643306, SAGE

[8] Turan, M. (1990) 'Vernacular Design and Environmental Wisdom', in Turan, M. (ed), Vernacular Architecture: Paradigms of Environmental Response Vol. 4 Avery, Gower Publishing Company England.

[9] Kotharker, R and Deshpande, R. (2012) A Comparative Study of Transformations in Traditional House Form: The Case of Nagpur Region, India, ISVS e-journal, Vol. 2, no. 2, pp 17-33.

[10] Dawdy, S. L. (2000) Understanding cultural change through the vernacular: creolization in Louisiana, Historical Archaeology 34 (3), pp 107-123.

[11] Wimsatt, W. C. (2014) Entrenchment and Scaffolding: an architecture for a theory of cultural change. In Developing Scaffolds in Evolution, Culture and Cognition, linnda R. Caporael, James R. Griesemer and William C. Wimsatt (eds). The MIT Press, Cambridge: Massachusetts, London: England.

[12] Tilley, C., Keane, W., Kuchler, S., Rowlands, M. and Spyer, P. (eds.) (2006) Handbook of Material Culture. London: Sage Publications Ltd. 
[13] Rapoport, A. and Hardie, G. (1991) 'Cultural change analysis: Core concepts of housing for the Tswana', in Tipple, G. and Willis, K. G. (eds) Housing the Poor in the Developing World - Methods of analysis, case studies and policy. Routledge, London.

[14] Baper, Y. S. (2018) The Role of Heritage Buildings in Constructing the Continuity of Architectural Identity in Erbil City, International Transaction Journal of Engineering, Management, \& Applied Sciences \& Technologies, 9 (1), pp $1-12$.

[15] Philokyprou, M. (2014) Continuities and Discontinuities in the Vernacular Architecture, Athens Journal of Architecture, Vol. $\mathrm{X}$, No. Y, pp 1-10.
[16] Yin, R. K. (2003) Applications of Case Study Research. Sage Publications.

[17] Lawrence, D. L. and Low, S. M. (1990) 'The Built Environment and Spatial Form', Annual Review of Anthropology, 19, pp. 453-505.

[18] Pader, E. (1993) 'Spatiality and social change: domestic space use in Mexico and the United States', American Ethnologist, 20 (1), pp. 114-137.

[19] Noussia, A. (2004) 'The Use of Domestic Space by Migrants on a Greek Island: Transformation or Translocation of Cultures?', Built Environment, 30, (1), pp. 60-75. 